Management for a Patient with Barret's Esophagus: A Case Report

by Muhammad Miftahussurur

Submission date: 27-Aug-2019 09:57AM (UTC+0800)

Submission ID: 1163831844

File name: SIPS_2017_88.pdf (240.02K)

Word count: 5342

Character count: 28960 


\title{
Management for a Patient with Barret's Esophagus: A Case Report
}

\author{
Muhammad Miftahussurur, Iswan Abbas Nusi, Poernomo Boedi Setiawan, Herry Purbayu, Titong \\ Sugihartono, Ummi Maimunah, Ulfa Kholili, Budi Widodo, Husin Thamrin and Amie Vidyani \\ Department of Internal Disease, Faculty of Medicine, Universitas Airlangga, Dr. Soetomo Teaching Hospital, Jl. Prof dr. \\ Moestopo 47 Surabaya 60132, Indonesia \\ apji@fk.unair:ac.id
}

Keyword: Barrett's Esophagus, Squamocolumnar, Gastroesophageal, Intestinal Metaplasia, Gastroesophageal Reflux Disease.

Abstract: Barrett's esophagus (BE) is a displacement of the squamocolumnar border (SCJ) site to proximal to the gastroesophageal junction (GEJ) accompanied by the presence of intestinal metaplasia. BE develops when reflux-induced stomach acid destroys the squamous epithelial layer of the esophagus and this lesion heals via a metaplasia process in which the damaged squamous epithelial layer is replaced by columnar colontype epithelium. BE prevalence in the general population is about $1.6-1.7 \%$. Patients with gastroesophageal reflux disease (GERD) may progress to BE. This report concerns two cases of patients with Barrett's esophagus. In both these patients $\mathrm{BE}$ was found without dysplasia. A diagnosis was made on the basis of anamnesis, physical examination, laboratory, radiological, endoscopy and anatomical pathology. The management of $\mathrm{BE}$ is aimed at three main objectives: reduction of symptoms due to GERD, avoiding progression to strictures and ulcers, and preventing progression to adenocarcinoma. Both patients were given a PPI, a prokinetic and chemoprevention NSAID which achieved clinical improvement. Neither patient had ablation, photodynamic or mucosal resection. BE survival is much better than in groups without BE (5 years survival $61 \%$ vs. $28 \%, P=0.001)$.

\section{INTRODUCTION}

The name Barrett's esophagus (BE) was coined when a London surgeon, R. Barrett N, described it in the 1950s. This definition continues to evolve, which initially included all of the three types of columnar epithelium, namely the fundal mucosa, cardia and intestinal metaplasia. However, there is currently a general consensus, namely the use of intestinal metaplasia and not using the other two types of mucosa, as markers for BE histology. The definition of $\mathrm{BE}$ according to the 4 American Gastroenterological Association is the displacement of the squamocolumnar border (SCJ) site to proximal to the gastroesophageal junction (GEJ) accompanied by the presence of intestinal metaplasia (Bansal, 2007; Pascu, 2004).

$\mathrm{BE}$ prevalence in the general population is about $1.6-1.7 \%$. Approximately $10-15 \%$ of patients with Gastroesophageal reflux disease (GERD) develop $\mathrm{BE}$, where the incidence of $\mathrm{BE}$ developing into adenocarcinoma is $0.5 \%$ per year. Compared to normal people, the risk of esophageal cancer is 3050 times, with an average age of 55-65 years. More than $80 \%$ are white with a $2: 1$ male to female ratio (Zanten et al., 2006; Wang, 2008; Poneros, 2009).

$\mathrm{BE}$ diagnosis is based on existing symptoms and risk factors, as well as the discovery of endoscopic layers of the columnar epithelium at the distal esophagus and is determined by the presence of intestinal metaplasia in biopsy specimens. BE is categorized based on how long the metaplasia layer limit is measured by endoscopy examination. It is called a long segment if its length is $3 \mathrm{~cm}$ or more, whereas if it is less than this it is called a short segment. If no columnar esophageal mucosa is found but intestinal metaplasia is via biopsy under the GEJ then it is called cardia intestinal metaplasia (CIM) (Bansal, 2007; Poneros, 2009; Spechler, 2002a)

$\mathrm{BE}$ develops when reflux-induced stomach acid destroys the squamous epithelial layer of the esophagus and this lesion heals via a metaplasia process in which the damaged squamous epithelial

438

Miftahussurur, M., Nusi, L., Setiawan, P., Purbayu, H., Sugihartono, T., Maimunah, U., Kholili, U., Widodo, B., Thamrin, H. and Vidyani, A.

Management for a Patient with Barret's Esophagus: A Case Report

In Proceedings of Surabaya International Physiology Seminar (SIPS 2017), pages 438-445

ISBN: 978-989-758-340-7

Copyright $\odot 2018$ by SCITEPRESS - Science and Technology Publications, Lda. All rights reserved 
layer is replaced by columnar colon-type epithelium. Studies have shown the presence of incompetent mechanics in the lower esophageal sphincter, low clearance, frequency and duration of reflux episodes, and peristaltic wave amplitude in both BE types is significantly lower than in normal people (Zentilin et al., 2002; Lord, 2003).

\section{CASE PRESENTATION}

\subsection{Case 1}

We report a male patient, $\mathrm{Mr} . \mathrm{H}$, aged 30 , unmarried, Chinese, bachelor's degree, working in a private company (marketing), living in Surabaya, who came for medication with a major complaint of heartburn in the chest.

The patient complained of heartburn in the chest for 14 years. It frequently recurs, and sometimes the burning sensation is up to the larynx. The complaints worsen if he lies flat, consumes fatty foods or coffee In addition, the patient complained of nausea, vomiting, bloating and heartburn. There was also constipation that disappeared causing him to often consume traditional medicine. There was no swallowing pain or swallowing difficulty, black feces and black vomiting like coffee, weight loss, or fatigue.

He first had recurring shortness of breath for 7 years before and was diagnosed with bronchitis. $\mathrm{He}$ had a history of maxillary sinusitis for 7 years. There was a history of a diet low in vegetables and fruit and a history of treatment with ranitidine and antacids. There were no smoking history, history of drinking alcohol, history of frequent drinking of coffee, history of traditional medicine (ching sung), high blood pressure and diabetes.

Based on a physical examination, it was found that his general condition was moderate, good awareness and was compos mentis. Blood pressure (BP) $120 / 80 \mathrm{mmHg}$, pulse $84 \mathrm{x} / \mathrm{min}$, axillary temperature $36.7^{\circ} \mathrm{C}$, respiration $20 \mathrm{x} / \mathrm{min}$ and body weight $89 \mathrm{~kg}$, Height of $173 \mathrm{~cm}$ and BMI 29.73. On examination of the head and neck no anemia, jaundice, cyanosis, dyspnea or enlarged lymph nodes (ELN) were found. Examination of the chest found symmetrical movement and no visible lagged chest breathing. First and second heart sounds is single, there was no noise in all ostia. Lung examination found no vesicular breathing sounds or rales and wheezing. On abdominal examination were found metorismus, bowel sound increase, unpalpable liver and spleen. Examination of the warm acral extremities, there was no edema or ELN. Laboratory results: $\mathrm{Hb} 13.6 \mathrm{~g} / \mathrm{dl}$, PCV 0.35, WBC 9,100/ ml, platelets (Plt) 404,000/ ml, blood sugar during 123 $\mathrm{mg} / \mathrm{dl}$, BUN $10 \mathrm{mg} / \mathrm{dl}$, serum creatinine SK) 1.1 $\mathrm{mg} / \mathrm{dl}$, AST $15 \mathrm{U} / \mathrm{L}$, ALT $13 \mathrm{U} / \mathrm{L}$, Sodium (Na) $123 \mathrm{meq} / \mathrm{L}$, Potassium (K) $3.29 \mathrm{meq} / 2 \mathrm{~L}$ and Albumin $4.1 \mathrm{~g} / \mathrm{dl}$, cholesterol total of $193 \mathrm{mg} / \mathrm{dl}$, LDL $139 \mathrm{mg} / \mathrm{dl}$, HDL $52 \mathrm{mg} / \mathrm{dl}$, triglyceride 68 $\mathrm{mg} / \mathrm{dl}, 5.9 \mathrm{mg} / \mathrm{dl}$ acids, HBsAg and non-reactive Anti-HCV.

Abdominal ultrasound found a lot of gas in the intestine. Hepar, lien, kidney, and gallbladder were within normal limits. Endoscopic examination found a mild patch of hyperemic spots with mucosal break of $7 \mathrm{~mm}$ and Barret's esophagus with a length of 2 $\mathrm{cm}$. The gastrointestinal and corpus portions were within normal limits, but hyperemia and erythema were present on the antrum of the pylorus. Thus, it was concluded to be GERD grade B and BE and superficial chronic gastritis were suspected. A biopsy was performed.

An anatomical pathology examination report (PA) found a gastric gland under the esophageal epithelium and no dysplasia or any signs of malignancy with a conclusion of BE. A gastric biopsy found chronic superficial gastritis and helicobacter pylori infection did not appear.

From anamnesis, physical examination, laboratory, radiologic, endoscopy and PA, the patient was diagnosed with GERD grade B + BE short segment without dysplasia + chronic superficial gastritis. The patient was advised to change their lifestyle and to undergo Rabeprazole therapy $2 \times 20 \mathrm{mg}$, domperidone $3 \times 10 \mathrm{mg}$, aspirin $100 \mathrm{mg}-0-0$. After 2 weeks of treatment the patient's condition improved. The patient was advised to continue the therapy and undergo another endoscopy one year later by 2 endoscopists.

\subsection{Case 2}

A female patient, Mrs. P, 49 years old, married, Chinese, bachelor's degree, a teacher, living in Surabaya came for treatment with major complaints of frequent bloating and heartburn.

She complained of frequent bloating and heartburn for 8 years, frequent recurrences, which improved with antacid administration and rest. This complaint is accompanied by a burning sensation in the chest when consuming spicy foods, coffee or tea. The patient also complained of a frequent sore throat for the past 5 years up to twice a month and often had swallowing pain. There were no black feces or vomiting, decreased weight or fatigue. 
There was a maxillary sinusitis 3 years ago. There was a history of coffee and tea consumption, omeprazole consumption (with a doctor's prescription) twice a day for 1 month, and no history of smoking, alcohol consumption, high blood pressure or diabetes.

A physical examination found that her general condition was moderate, with good awareness and was compos mentis. Blood pressure (BP) was $110 / 70 \mathrm{mmHg}$, pulse $82 \times / \mathrm{min}$, axillary temperature $36.7^{\circ} \mathrm{C}$, respiration $20 \mathrm{x} / \min$ and body weight $60 \mathrm{~kg}$ TB $153 \mathrm{~cm}$ BMI 25.63. Examination of the head and neck did not find anemia, jaundice, cyanosis, dyspnea or enlarged lymph nodes (ELN). Examination of the chest did not find asymmetrical movement and there was no visible lagged chest breathing. First and second heart sounds is single, no noise in all ostia. Lung examination found vesicular breathing sounds with no rhonchi and wheezing. Examination of the stomach found meteorismus, increased bowel sounds, and the liver and lien were not palpable. The examination of the warm acral extremities did not find edema and ELN.

Laboratory results: $\mathrm{Hb} 12.1 \mathrm{~g} / \mathrm{dl}$, PCV 0.36 , WBC $6510 / \mathrm{ml}$, platelets (Plt) $316,000 / \mathrm{ml}$, fasting blood sugar $112 \mathrm{mg} / \mathrm{dl}$, blood sugar 2 JPP $126 \mathrm{mg}$ / dl serum creatinine (SK), LDL $91 \mathrm{mg} / \mathrm{dl}$, HDL 38 $\mathrm{mg} / \mathrm{dl}$, Triglyceride $147 \mathrm{mg} / \mathrm{dl}$, Acid vein $4.4 \mathrm{mg}$ / dl.

Endoscopic examination found a mild patch of hyperemic spots with a mucosal break of $6 \mathrm{~mm}$ and a Barret esophageal picture with a length of $5 \mathrm{~cm}$ The gastrointestinal and corpus segments were within normal limits, but hyperemia and erythema were detected on the antrum and angulus segment. Thus, it was concluded as GERD grade $\mathrm{B}$ and $\mathrm{BE}$ and superficial chronic gastritis were suspected. A biopsy was performed.

PA examination reported that under the esophageal epithelium there were gastric glands, but no dysplasia or any signs of malignancy with the conclusion of BE. In gastric biopsy, chronic superficial gastritis was found and helicobacter pylori infection did not appear.

From the results of the anamnesis, physical examination, laboratory, endoscopy and PA, the patient was diagnosed as GERD grade $\mathrm{B}+\mathrm{BE}$ long segment without dysplasia + chronic superficial gastritis. The patient was advised to change her lifestyle and undergo $2 \times 40 \mathrm{mg}$ of esomeprazole therapy, $3 \times 10 \mathrm{mg}$ of domperidone, aspirin $100 \mathrm{mg}$ $0-0$, and ranitidine $150 \mathrm{mg}$ before bed. The patient's condition got better after one month of therapy. The patient was advised to continue the therapy and have another endoscopy one year later by 2 endoscopists.

\section{DISCUSSION}

For decades, BE was identified primarily in patients with severe GERD based on the long segmental findings of columnar epithelial extending more than $3 \mathrm{~cm}$ above the gastroesophageal junction (Spechler, 2002a). Clinically BE does not give symptoms; most people complain because of symptoms of GERD (Table 1). The most common symptoms of GERD are heartburn or pyrosis, regurgitation, and dysphagia. Heartburn, defined as heat in the retrosternal region, has a specificity of $89 \%$ and a positive predictive value of $81 \%$ for GERD. Regurgitation, defined as a reflux sensation from the stomach to the mouth or hypopharynx, has a $95 \%$ specificity and a $57 \%$ positive predictive value for GERD. The classic GERD symptoms rarely require confirmatory tests because they have a high positive predictive value and are sufficient to make a diagnosis in the majority of cases. In fact, the combination of heartburn and regurgitation has an accuracy greater than $90 \%$ for diagnosing GERD (Hirano, 2007).

Extraesophageal or atypical manifestations are quite common in patients with GERD. As many as $80 \%$ of patients with GERD symptoms may have at least one extra esophageal manifestation (Kamat, 2008). GERD causes coughing in $40 \%$ of patients and GERD is found in $34-89 \%$ of patients with asthma (Hirano, 2007). Sinusitis may be a manifestation of GERD either directly injuring the sinus mucosa or causes vagus-mediated neuro inflammatory changes or both (Jecker et al., 2006).

Table 1: Symptoms of Gastro esophagus reflux disease.

\begin{tabular}{llll}
\hline $\begin{array}{l}\text { Esophageal } \\
\text { Manifestation }\end{array}$ & \multicolumn{3}{l}{$\begin{array}{l}\text { An extraesophageal or atypical } \\
\text { manifestation }\end{array}$} \\
\cline { 2 - 4 } & Oral & ENT & Lung \\
\hline Heartburn & $\begin{array}{l}\text { Water- } \\
\text { brash }\end{array}$ & Hoarseness & Asthma \\
\hline Regurgitation & $\begin{array}{l}\text { Burning } \\
\text { sensation } \\
\text { in mouth }\end{array}$ & Dysphonia & Bronchitis \\
\hline Dysphagia & $\begin{array}{l}\text { Tongue } \\
\text { sensitivity }\end{array}$ & Sore throat & Pneumonia \\
\cline { 2 - 4 } & $\begin{array}{l}\text { Halitosis } \\
\text { Chronic }\end{array}$ & $\begin{array}{l}\text { Idiopathic } \\
\text { pulmonary } \\
\text { cough }\end{array}$ \\
& & fibrosis \\
\hline
\end{tabular}

Source: (Kamat, 2008) 
In patient I there were heartburn, nausea, vomiting, bloating and heartburn. There was a history of bronchitis and maxillary sinusitis for 7 years that may be associated with GERD. In patient II frequent bloating and heartburn, a frequent sore throat and pain on swallowing were found. There was a history of maxillary sinusitis for 3 years probably related to GERD.

Screening is recommended for patients who have a high risk of developing BE, i.e. male, white, aged $>40$, duration of old GERD complaints of $>13$ years, smokers, and obesity (Sharma, 2005; Wang, 2008). Increased BMI is a major contributor to the development of GERD, which in turn is a known risk factor for BE. Increased levels of proinflammatory cytokines (adipocytokines) including interleukin- 6 and tumor necrosis factor- $\alpha$, associated with visceral fat, have been shown to be expressed in patients with BE. Various biological mediators including leptin, insulin and insulin-like growth factors, which are closely related to obesity, are shown to stimulate cell proliferation and inhibit apoptosis. This may be similar to the mechanisms underlying the development of esophageal neoplasia (Kamat, 2008; Sharma, 2005).

In patient I screening was recommended because he was male, having the duration of GERD of 14 years and BMI of above normal. While in patient II the risk was the age of $>40$ and BMI of above normal. The American College of Gastroenterology provides guidelines for the diagnosis of GERD, which provides empirical therapy of acid suppressant drugs in addition to lifestyle modification if the patient has symptoms of uncomplicated GERD. Empirical therapy is in the form of the provision of a proton pump inhibitor (PPI) such as omeprazole $20-40 \mathrm{mg}$ twice daily for 1 week. One study reported that an assessment of 40 mg omeprazole response for 2 weeks had the same diagnostic efficacy value as gastric $\mathrm{pH}$ testing (Kamat, 2008). Uterine endoscopic examination (Upper Gastrointestinal) is a golden standard for the diagnosis of GERD with the presence of mucosal breaks in the esophagus (Table 2). It is included in grade $\mathrm{B}$ if the mucosal break is more than $5 \mathrm{~mm}$ but does not extend to the peak of the folds of two mucosa.

In both patients there was a mucosal break $>5$ $\mathrm{mm}$ but did not extend to the peak of two mucous folds, thus including grade $\mathrm{B}$.

Measurement of the length of the BE segment requires the important participation of an endoscopist, because the presence of large hiatus hernia, ulcers / erosions, strictures etc., can reduce the accuracy of the assessment leading to overdiagnosis. The method of measurement is to start by identifying the gastroesophageal junction (GEJ) and squamocolumnar junction (SCJ) accurately, then measure the distance between the proximal SCJ and GEJ measured by endoscopy and recorded as the length of the BE segment (Bansal, 2007). The length of the segment will confirm the high risk of progressive progression to adenocarcinoma. Long segments have an esophageal cancer risk 30 times greater than the general population.

Table 2: Modification of the Los Angeles classification for GERD.

\begin{tabular}{cl}
\hline Grade & \multicolumn{1}{c}{ Description } \\
\hline $\mathrm{A}$ & $\begin{array}{l}\text { Break of mucosa of }<5 \mathrm{~mm} \text { but does not } \\
\text { extend to the peak of two mucosa folds. }\end{array}$ \\
\hline $\mathrm{B}$ & $\begin{array}{l}\text { Break of mucosa of }>5 \mathrm{~mm} \text { but does not } \\
\text { extend until peak folds of two mucosae. }\end{array}$ \\
\hline $\mathrm{C}$ & $\begin{array}{l}\text { The mucosal break extends to the peak } \\
\text { of two mucosa folds but less than } 75 \% \text { of } \\
\text { the esophageal periphery. }\end{array}$ \\
\hline $\mathrm{D}$ & $\begin{array}{l}\text { Mucosal breaks extend to the top of two } \\
\text { mucosa folds over } 75 \% \text { of the } \\
\text { esophageal periphery }\end{array}$ \\
\hline Source (Lichtenstein et al., 2007)
\end{tabular}

Several new imaging modalities are proposed to help establish the diagnosis of BE. The currently commercially available technique is narrow band imaging (NBI), a method of filtering light into two main colors, blue and green, which means more is absorbed by the blood vessels in the mucosa and subepithelium. This difference helps the endoscopist to see the mucosa better, let alone combined with high-resolution endoscopy. The sensitivity of NBI for the detection of irregular mucosal patterns is $100 \%$ with a specificity of $98.7 \%$. Another modality is autofluorescence imaging, a technology that uses blue lighting to detect fluorescence from cellular components in the esophagus. The dysplasia region does not have as intense autofluorescence as normal tissue and appears dark red. A study found that autofluorescence was $100 \%$ sensitive for high-class regions of dysplasia in 20 patients, but had a falsepositive rate of $40 \%$. Other contrast agents such as violet crystal, indigo carmine, and acetic acid have also been proposed to improve the detection of mucosal patterns in Barrett's esophagus in combination with high-resolution endoscopes. Although very promising, there is not enough current evidence to recommend the use of clinically routine imaging systems (Wang, 2008). 
In Patient $\mathrm{I}$, there was a long segment of $\mathrm{BE}$ of 2 $\mathrm{cm}$, which included a short segment, whereas in patient II the segment length was $5 \mathrm{~cm}$ so it included a long segment, so theoretically had a higher risk of esophageal cancer.

Dysplasia is a histological diagnosis showing that one or more epithelial cell clones have undergone a genetic alteration that makes them neoplastic and prone to malignancy (Spechler, 2002a). The diagnosis of BE biopsy was classified with no dysplasia, low-grade dysplasia and highgrade dysplasia. Low-grade dysplasia is most commonly found and is a cause of cancer. In its development, low grade can turn into high grade then sometimes turns into cancer (Poneros, 2009).

In both patients there was no dysplasia, then diagnose as $\mathrm{BE}$ without dysplasia.

In 2008, the American College of Gastroenterology recommended that the class of dysplasia determines the interval of surveillance (Table 3)

Table 3: Grade of dysplasia, management and surveillance recommendations.

\begin{tabular}{|c|c|c|c|}
\hline No & $\begin{array}{l}\text { Grade of } \\
\text { dysplasia }\end{array}$ & Management & $\begin{array}{c}\text { Surveillance } \\
\text { recommendati } \\
\text { on }\end{array}$ \\
\hline 1 & $\begin{array}{l}\text { No } \\
\text { dysplasia }\end{array}$ & $\begin{array}{l}2 \text { endoscopies } \\
\text { with biopsy for } \\
\text { confirmation } \\
\text { within } 1 \text { year }\end{array}$ & $\begin{array}{l}\text { No dysplasia, } \\
\text { endoscopy } \\
\text { every } 3 \text { years }\end{array}$ \\
\hline 2 & $\begin{array}{l}\text { Low- } \\
\text { grade } \\
\text { dysplasia }\end{array}$ & $\begin{array}{l}\text { Confirmed by a } \\
\text { PA expert, } \\
\text { endoscopy with } \\
\text { biopsy every } 6 \\
\text { months }\end{array}$ & $\begin{array}{l}\text { High-grade } \\
\text { dysplasia } \\
\text { endoscopy is } \\
\text { performed / yr } \\
\text { to no } \\
\begin{array}{l}\text { dysplasia } \\
\text { obtained at } 2 \\
\text { checks }\end{array}\end{array}$ \\
\hline 3 & $\begin{array}{l}\text { High- } \\
\text { grade } \\
\text { dysplasia }\end{array}$ & $\begin{array}{l}\text { Confirmed by a } \\
\text { PA expert } \\
\text { Irregular } \\
\text { Mucosa: } \\
\text { consider } \\
\text { mucosal } \\
\text { resection with } \\
\text { endoscopy. } \\
\text { Flat mucosa: } \\
\text { repeat and } \\
\text { endoscopy and } \\
\text { biopsy every } 3 \\
\text { months }\end{array}$ & $\begin{array}{l}\text { Confirms the } \\
\text { presence of } \\
\text { High-grade } \\
\text { dysplasia, } \\
\text { months of } \\
\text { intensive } \\
\text { surveillance, } \\
\text { esophagectom } \\
\text { y, endoscopic } \\
\text { therapy. }\end{array}$ \\
\hline
\end{tabular}

Source: (Kamat, 2008)

Endoscopic surveillance should be performed in chronic GERD patients. Ideally symptoms can be controlled with acid suppression therapy. This is important because the inflammatory process associated with reflux esophagitis may interfere with the diagnosis and BE grading and may even be similar to dysplasia. Endoscopic BE monitoring involves 4 quadrants and a biopsy taken every 1 to 2 $\mathrm{cm}$ across the Barrett segment. For patients with intestinal metaplasia (without dysplasia), surveillance endoscopy should be performed twice in the first year to exclude dysplasia changes. Patients with low-grade dysplasia should undergo endoscopic follow up at 6 months from initial screening to exclude progression to high-grade dysplasia. Patients with high-grade dysplasia in the form of flat mucosa should be referred to a special center for further diagnostic evaluation and confirmation of the diagnosis by a gastrointestinal PA expert with endoscopies in the next 3 months (Kamat, 2008; Sharma, 2005).

In both patients $\mathrm{BE}$ was found without dysplasia, so endoscopic surveillance was planned again after 1 year by two endoscopists.

Peitz et al. detected Helicobacter pylori (HP) in $50 \%$ of subjects, independent of BE length (Tuncer et al., 2003). Some researchers have hypothesized that the presence of HP infections may have protective effects on the esophagus against esophageal cancer, as the gastric acid output is reduced (Spechler, 2002a; Laheij et al., 2002).

In both these patients there was no helicobacter pylori infection.

- Several studies have determined risk factors for progression to adenocarcinoma in $\mathrm{BE}$ patients (Table 4). Genetic abnormalities, developmental abnormalities of tumor suppressor genes, p16 and $\mathrm{p} 53$, as well as the development of tetraploid and aneuploid cell populations detected through flow cytometry and fluorescence are situ hybridization (FISH). Increased gastro-esophageal reflux is associated with increased abnormalities of biomarkers at all stages of molecular development, including p16, p53, tetraploidy and aneuploidy (Poneros, 2009; Souza et al., 2001; Jankowski, 2004).

In patient I risk factors for development into adenocarcinoma are a low-fat diet and fruit, increased BMI, make gender, heartburn and lack of a PPI. Patient II had risk factors of being $>40$, BMI increase and $\mathrm{BE}$ long segment. Biomarkers were not performed on these two patients.

The management of $\mathrm{BE}$ is aimed at three main objectives: reduction of symptoms due to GERD, avoiding progression to strictures and ulcers, and preventing progression to adenocarcinoma. Changes in lifestyle that must be done are BB reduction, 
sleeping with head elevation, and avoiding smoking, fatty foods, coffee, chocolate, alcohol and orange juice. Reduction of GERD symptoms by using suppression of gastric acid secretion by administration of a H2-Antagonist Receptor (H2RA) or PPI. 3The success of antisecretic therapy for GERD is directly related to the degree of acid suppression achieved and inversely related to the severity of the underlying esophageal reflux. The presence of incompetent mechanics in the lower esophageal sphincter, low clearance, frequency and duration of reflux episodes, peristaltic wave amplitude in both BE types significantly lower than that of normal people are the basic concepts of GERD pathogenesis. So prokinetic drugs such as metoclopramide, domperidone and cisapride are only used as an adjuvant PPI and not given as a monotherapy (Fitzgerald, 2004; Schuchert, 2007).

Table 4: Risk factors for development into adenocarcinoma in patients with Barret's Esophagus.

\begin{tabular}{|c|c|c|c|}
\hline \multicolumn{2}{|c|}{ Clinical Factor } & \multirow{2}{*}{$\begin{array}{l}\begin{array}{c}\text { Endoscopy } \\
\text { Factor }\end{array} \\
\text { Large } \\
\text { hiatal } \\
\text { hernia }\end{array}$} & \multirow{2}{*}{$\begin{array}{l}\begin{array}{c}\text { Histology } \\
\text { factor }\end{array} \\
\begin{array}{l}\text { High-grade } \\
\text { dysplasia }\end{array}\end{array}$} \\
\hline $\begin{array}{l}\text { Diet low } \\
\text { in } \\
\text { vegetabl } \\
\text { es and } \\
\text { fruit }\end{array}$ & $\begin{array}{l}\text { Working } \\
\text { in } \\
\text { hunchback } \\
\text { position }\end{array}$ & & \\
\hline $\begin{array}{l}\text { Increase } \\
\text { d BMI }\end{array}$ & $\begin{array}{lr}\text { Lack of } \\
\text { using a } \\
\text { PPI }\end{array}$ & $\begin{array}{l}\text { BE long } \\
\text { segment }\end{array}$ & \\
\hline Male & $\begin{array}{l}\text { Symptoms } \\
\text { of } \\
\text { heartburn }\end{array}$ & $\begin{array}{l}\text { Mucosal } \\
\text { abnormalit } \\
\text { ies }\end{array}$ & Biomarker \\
\hline Old Age & Use of & Nodularity & Aneuploidy \\
\hline Smoker & drugs that & Ulceration & P53 loss of \\
\hline $\begin{array}{l}\text { Alcohol } \\
\text { consume } \\
\mathrm{r}\end{array}$ & $\begin{array}{l}\text { relax the } \\
\text { lower } \\
\text { esophageal } \\
\text { sphincter }\end{array}$ & Stricturing & $\begin{array}{l}\text { heterozygosi } \\
\text { ty }\end{array}$ \\
\hline
\end{tabular}

Patients I and II were recommended lifestyle changes and were given a PPI and prokinetic.

All patients with $\mathrm{BE}$ should be given a PPI although there are no symptoms of GERD. A longterm retrospective study of 236 patients with $\mathrm{BE}$ who received a number of different anti-reflux therapies showed that in 10 years, the incidence of cumulative dysplasia was $21 \%$ in patients receiving a PPI compared with $58 \%$ in patients who did not receive a PPI or H2RA. Another study showed that the risk of developing low-grade dysplasia was 5.6 times higher in patients who started PPI therapy 2 years or more after the diagnosis than in patients starting PPI therapy in the first year. In addition, delayed PPI therapy may increase the risk of progression to high-grade dysplasia or adenocarcinoma by $20.9 \%$. Some researchers advise to add H2RA at night in addition to the use of a PPI twice daily to reduce acid relief (Chen et al., 2002; Sabel et al., 2000).

Currently there are 1 five types of PPI with comparable efficacy of omeprazole $(20 \mathrm{mg} /$ day), lansoprazole (30 mg / day), Rabeprazole (20 mg / day), Pantoprazole ( $40 \mathrm{mg} /$ day) and esomeprazole (40 mg / day). Research using two types of PPI approved by the Food and Drug Administration (FDA), giving once or twice daily oral esomeprazole shows the ability to control significantly the intragastric acidity compared to equivalent doses of lansoprazole in Patients with BE. Twice daily doses of the drug give better control of the intragastric $\mathrm{pH}$ than once-daily dosing, and both exhibit a relative advantage of controlling intragastric acid with increasing dosage in $75 \%$ of patients with $\mathrm{BE}$ (Jankowski, 2004; Spechler et al., 2002b). Ortiz et al. suggested monitoring gastric $\mathrm{pH}$ in the titration process of PPI dosing (Hirano, 2007).

Patient II was given $2 \times 40 \mathrm{mg}$ of esomeprazole PPI with $150 \mathrm{mg}$ of ranitidine added in the evening. Patient I was given $2 \times 20 \mathrm{mg}$ of Rabeprazole.

Anti-reflux surgery is attempted by creating a barrier to gastroesophageal reflux through an esophagus packing by the fundus of the stomach (fundoplication). This is usually performed in patients with low comorbidity and the presence of symptoms of reflux despite being treated with a PPI. But the long-term results are disappointing with a 5year failure rate of $20 \%$ (Wang, 2008). Initially, some researchers argued that the possibility of fundoplication is more effective than a PPI to prevent cancer deaths due to BE. Two recent studies provide little support for this opinion, but in one randomized trial of medical and surgical therapy in 247 complicated GERD patients, adenocarcinoma of the esophagus occurred in four of the 165 patients in the medical group (2.4 percent) and one of 82 in the surgical group (1.2 percent) during follow up 10 to 13 years with a statistically non-significant difference (Wang, 2008; Spechler, 2002a). Baulieux et al. reported complete or partial regression of $27 \%$ in patients undergoing fundoplication and $7.1 \%$ with PPI therapy. Ortiz et al. reported regression in $32 \%$ with fundoplication versus $7 \%$ with PPI on BE found at segment length (Lord, 2003). Medical and surgical therapy is very effective for correcting or relieving symptoms and signs of GERD, but has not been shown to reduce the risk of esophageal 
adenocarcinoma (Fitzgerald, 2004; Cooper et al., 2006)

In both these patients anti-reflux surgery was not performed.

Chemoprevention in the prevention of adenocarcinoma of the esophagus represented by $\mathrm{BE}$ is considered quite rational. The best evidence of use of chemoprevention agents is Cyclooxygenase (COX) -2 inhibitors and $325-\mathrm{mg}$ enteric-coated aspirin daily has been shown in several epidemiological studies and is associated with a significantly reduced cancer risk with a 0.57 odds ratio $(95 \%$ CI $0.47-0.71)$. This decrease in risk can be attributed to the effect on cyclo-oxygenase-2 mucosal expression (COX-2) and prostaglandin E2 production (PGE2), as both are associated with the development of $\mathrm{BE}$ into adenocarcinoma. Tsibouris et al. proved that $\mathrm{BE}$ patients with esophageal adenocarcinoma were rarely consumed NSAIDs (Poneros, 2009; Fitzgerald, 2004).

Both patients were given aspirin $100 \mathrm{mg}-0-0$. Ablation therapy, ablation with thermal energy (thermal ablation), photodynamics, and endoscopic mucosal resection have now been widely used for $\mathrm{BE}$ high-grade or early-stage care. However, the lack of data on the usefulness of these therapies for $\mathrm{BE}$ without dysplasia is therefore not recommended. In the future, biomarkers may be able to provide better risk stratification to justify endoscopic ablation therapy for non-displaced BE (Poneros, 2009; Wolfsen et al., 2002; Schuchert, 2007).

In both patients there was no ablation, photodynamic or mucosal resection.

Survival in the BE group was much better than the group without $\mathrm{BE}$ (5 years survival $61 \%$ vs. $28 \%, \mathrm{P}=0.001$ ). Adenocarcinoma of the esophagus is not a common cause of death in BE patients; the most common cause is bronchopneumonia and ischemic heart disease (Portale et al., 2005; Sabel et al., 2000).

\section{CONCLUSION}

This report concerns two cases of patients with Barrett's esophagus. In both these patients $\mathrm{BE}$ was found without dysplasia. Diagnosis was made on the basis of anamnesis, physical examination, laboratory, radiological, endoscopy and anatomical pathology. The management of BE is aimed at three main objectives: reduction of symptoms due to GERD, avoiding progression to strictures and ulcers, and preventing progression to adenocarcinoma. Both patients were given a PPI, Prokinetic and Chemoprevention NSAID which achieved clinical improvement. Both patients had no ablation, photodynamic or mucosal resection. BE survival is much better than in groups without BE ( 5 years survival $61 \% \mathrm{vs}$. $28 \%, \mathrm{P}=0.001)$.

\section{REFERENCES}

BANSAL, A. A. S., P. 2007. Definition and Diagnosis of Barrett's Esophagus. , 2nd edition. , Blackwell Publishing Ltd.

CHEN, L. Q., HU, C. Y., SARKISSIAN, S. D., FERRARO, P., PERA, M. \& DEBLOIS, D. 2002. Apoptosis in barrett's oesophagus following antireflux surgery. . British journal of surgery 89, , 1444-49.

COOPER, B. T., CHAPMAN, W., NEUMANN, C. S. \& GEARTY, J. C. 2006. Continuous treatment of Barrett's oesophagus patients with proton pump inhibitors up to 13 years: observations on regression and cancer incidence. . Aliment Pharmacol Ther 23, 727-733.

FITZGERALD, R. C. 2004. Review article: Barrett's oesophagus and associated adenocarcinoma - a UK perspective. . Aliment Pharmacol Ther, 20, 45-49

HIRANO, I. A. R., J.E. 2007. ACG Practice Guidelines: Esophageal Reflux Testing. Am J Gastroenterol, 102, , 668-85

JANKOWSKI, J. A. S., P. 2004. Review article: approaches to Barrett's oesophagus treatment-the role of proton pump inhibitors and other interventions. Aliment Pharmacol Ther, , 19 (Suppl. 1), 54-59.

JECKER, P., ORLOFF, L. A., WOHLFEIL, M. \& MANN, W. J. 2006. Gastroesophageal reflux disease (GERD), extraesophageal reflux (EER) and recurrent chronic rhinosinusitis. Eur arch otorhinolaringeal 263, , 664-67.

KAMAT, P. P. A. A. 2008. Barrett's Esophagus: Evaluation and Management. JCOM . 15, 402-11.

LAHEIJ, R. J., VAN ROSSUM, G. M., DE BOER, W. \& JANSEN, B. M. 2002. Corpus gastritis in patients with endoscopic diagnosis of reflux oesophagitis and Barrett's oesophagus. . Aliment Pharmacol Ther 16, , 887-91

LICHTENSTEIN, D. R., CASH, B. D., , DAVILA, R. BARON, T., ADLER, B. \& ANDERSO, M., ET AL 2007. Role of endoscopy in the management of GERD. Gastrointestinal endoscopy 6, , 219-2

LORD, R. V. 2003. Antireflux surgery for barrett's oesophagus. . ANZ J. Surg., 73, , 234-46.

PASCU, O. A. L., M. 2004. Barrett's oesophagus. Romanian journal of gastroenterology 13, , 219-22.

PONEROS J, M. 2009. Barrett esophagus, , The McGrawHill Companies,

PORTALE, G., PETERS, J., HAGEN, J. A., . DEMEESTER, R. S. \& GANDAMIHARDJA T, T. C. E. A. 2005. Comparison of the clinical and histological characteristics and survival of distal esophageal-gastroesophageal junction adenocarcinoma 
in patients with and without barrett mucosa. . Arch Surg,, 140:, 570-575.

SABEL, M., PASTORE, K., TOON, H. \& SMITH, J. L. 2000. Adenocarcinoma of the Esophagus With and Without Barrett Mucosa. Arch Surg. , 135,, 831-35.

SCHUCHERT, M. A. L., J. 2007. Barrett's EsophagusEmerging Concepts and Controversies, . Journal of Surgical Oncology, 95:, 185-9.

SHARMA, P. A. S., E.I. 2005. Are screening and surveillance for barrett's oesophagus really worthwhile? . Gut 54, , i27-32.

SOUZA, R. F., MORALES, C. P. \& SPECHLER, S. J. 2001. Review article: a conceptual approach to understanding the molecular mechanisms of cancer development in Barrett's oesophagus. Aliment Pharmacol Ther 15, 108-100.

SPECHLER, S., J,, BARKER, P. N. \& SILBERG, D. G. 2002b. Clinical trial: intragastric acid control in patients who have Barrett's oesophagus-comparison of once- and twice-daily regimens of esomeprazole and lansoprazole. Aliment Pharmacol Ther 30, 138-145.

SPECHLER, S. J. 2002a. Barrett's oesophagus. N Engl J Med 346, , 836-42.

TUNCER, I., UGRAS, S., UYGAN, I., TURKDOGAN, K. \& KOSEM, M. 2003. The association of short segment Barrett's esophagus with intestinal metaplasia in stomach. . Turk J Gastroenterol 1, , 33-381.

WANG, K. K. A. S., R.E. 2008. Updated Guidelines 2008 for the Diagnosis, Surveillance and Therapy of Barrett's Esophagus. Am J Gastroenterol 103, , 78897)

WOLFSEN, H. C., WOODWARD, T. A. \& RAIMONDO, M. 2002. Photodynamic Therapy for Dysplastic Barrett Esophagus and Early Esophageal Adenocarcinoma. . Mayo Clin Proc. , 77, , 1176-81.

ZANTEN, S.J., , THOMSON, A. B., BARKUN, A. N. ARMSTRONG, A. D., CHIBA \& WHITE, R. J., ET AL 2006. The prevalence of Barrett's oesophagus in a cohort of 1040 Canadian primary care patients with uninvestigated dyspepsia undergoing prompt endoscopy. . Aliment Pharmacol Ther 23, , 59-99.

ZENTILIN, P., CONIO, M., MANSI, C. \& PANDOLFO, N., DULBECCO P, GAMBARO C, ET AL 2002 Comparison of the main oesophageal pathophysiological characteristics between short- and long-segment barrett's Oesophagus. Aliment Pharmacol Ther $16,, 893-8$ 
Management for a Patient with Barret's Esophagus: A Case Report

ORIGINALITY REPORT

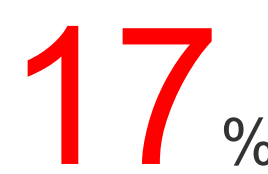

SIMILARITY INDEX
$8 \%$

INTERNET SOURCES
$17 \%$

PUBLICATIONS
$0 \%$

STUDENT PAPERS

\section{PRIMARY SOURCES}

\section{1 gi.org}

Internet Source

2 S. J. SPECHLER. "Clinical trial: intragastric acid control in patients who have Barrettâ $s$ oesophagusâ comparison of once- and twicedaily regimens of esomeprazole and lansoprazole", Alimentary Pharmacology \& Therapeutics, 07/2009 Publication

3 Stuart Jon Spechler. "Barrett's Esophagus", New England Journal of Medicine, 03/14/2002 Publication

\section{Ajay Bansal. "Definition and Diagnosis of}

Barrett's Esophagus", Barrett s Esophagus and Esophageal Adenocarcinoma, 05/05/2006 Publication

Mushtaque, AR. "Gastroesophageal Reflux

Disease â€" An Update", Bangladesh Journal of Medical Science, 2010. 
6 ats.ctsnetjournals.org

7 J. Jankowski. "Approaches to Barrett's

oesophagus treatment-the role of proton pump inhibitors and other interventions", Alimentary

Pharmacology and Therapeutics, 2/2004

Publication

8 eprints.soton.ac.uk

Internet Source

$9 \quad$ www2.gov.bc.ca Internet Source

10 Absolute Nephrology Review, 2016.

Publication

11 L Rodrigo. "Healing of Oesophagitis", Drugs, 2005

Moraes-Filho, Joaquim Prado P., Tomas

Navarro-Rodriguez, Ricardo Barbuti, Jaime

Eisig, Decio Chinzon, and Wanderley Bernardo.

"Guidelines for the diagnosis and management

of gastroesophageal reflux disease: an

evidence-based consensus", Arquivos de

Gastroenterologia, 2010.

Publication

Kenneth K. Wang. "Current strategies in the 
management of Barrett's esophagus", Current

Gastroenterology Reports, 2005

Publication

14

Liu, Shuzheng, James Y. Dai, Lena Yao,

Xiaohong Li, Brian Reid, Steve Self, Jie Ma,

Yuxi Chang, Shixian Feng, Jean de Dieu

Tapsoba, Xin Sun, and Xibin Sun. "Esophageal

Adenocarcinoma and Its Rare Association with

Barrett's Esophagus in Henan, China", PLoS

ONE, 2014.

Publication

15

Wang, K.K.. "American Gastroenterological

Association Technical Review on the Role of the

Gastroenterologist in the Management of

Esophageal Carcinoma", Gastroenterology,

200505

Publication

16 www.powershow.com

Internet Source

17 cancerres.aacrjournals.org

Internet Source

18 cancer.swedish.org

Internet Source

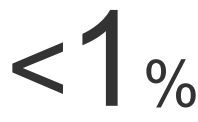

19 file.scirp.org

Internet Source

Ramzy, Iman, Mohamed El Shazly, Raghda 
- Marzaban, Tamer Elbaz, Mina Safwat, and Botros Latif. "Laryngopharengeal Reflux in Gastroesophageal Reflux Disease: Does "Silent Laryngopharengeal Reflux" Really Exist?", Open Journal of Gastroenterology, 2014.

Publication

\section{1}

Jerrold B. Leikin. "Foreword", Disease-a-Month, 2018

Publication

22 www.turkgastro.org

"Therapeutic Lipidology", Springer Nature, 2008

Exclude quotes

Exclude bibliography 


\section{Management for a Patient with Barret's Esophagus: A Case Report}

GRADEMARK REPORT

FINAL GRADE

10

PAGE 1

PAGE 2

PAGE 3

PAGE 4

PAGE 5

PAGE 6

PAGE 7

PAGE 8
GENERAL COMMENTS

Instructor 